\title{
Anatomy of Carlina corymbosa L., Carthamus dentatus Vahl. and Picnomon acarna (L.) Cass. (Asteraceae)
}

\author{
Ummahan Öz ${ }^{1 *(i D)}$ \\ ${ }^{1}$ Department of Plant and Animal Production, Alaşehir Vocational School, Manisa Celal Bayar University, Manisa \\ Turkey \\ *ummahanoz48@gmail.com \\ *Orcid: 0000-0002-0281-1048
}

Received: 25 August 2020

Accepted: 19 April 2021

DOI: $10.18466 /$ cbayarfbe. 785328

\begin{abstract}
Species of Carlina corymbosa L., Carthamus dentatus Vahl. and Picnomon acarna (L.) Cass. are belonging to Asteraceae family. The purpose of the study is to determine the anatomical structures of these species in the same tribe and to compare the features. Samples of root, stem and leaf of each species were collected, fixed and examined using a light microscope. In addition, some anatomical features were measured. Secondary growth was observed in the root cross section of each species. Secretory ducts were determined in all species. While the pith is filled with xylem elements in C. corymbosa and C. dentatus, the pith of $P$. acarna consists of different shaped parenchyma cells. Periderm was observed in the stem in all species. All species contain bicollateral vascular bundles in stem. In all species, glandular and nonglandular trichomes were observed on the leaf cross section, on the surface of the adaxial and abaxial epidermis. While $C$. corymbosa has dorsiventral mesophyll, unifacial mesophyll is observed in other species. There is bicollateral vascular bundle in $C$. corymbosa whereas collateral vascular bundle was identified in $C$. dentatus and $P$. acarna. Also, $C$. corymbosa and $C$. dentatus have only one vascular bundle in the midrib but P.acarna has three vascular bundles.
\end{abstract}

Keywords: Anatomy, bicollateral, collateral, dorsiventral, secretory duct, unifacial.

\section{Introduction}

Carlina corymbosa L., Carthamus dentatus Vahl. and Picnomon acarna (L.) Cass. are member of Asterales order, Asteraceae family, Carduoideae subfamily and Cardueae tribe [1].

The Asteraceae family is represented in the world with about 1911 genera and 32913 species [2]. In Turkey, there are 133 genera and 1156 species belonging to this family and tribe of Cardueae includes 39 genera and approximately 500 taxa [3-4].

The taxa belonging to Cardueae have morphological similarity features and these similarities cause problems in classification. In taxonomic studies, it is seen that only the use of morphological characters is insufficient and therefore, the necessity of anatomical, cytological, molecular, palynological studies etc. is revealed [5].

There are anatomical differences in the species belonging to Asteraceae family. In this family, the secretory structures (cavities, idioblast, ducts and trichomes etc.) are important anatomical characters and these structures are used for identification the species. For example, the micromorphology of trichome is a feature that can be used in the systematics of the Asteraceae [6]. Glandular and non-glandular trichomes are used as distinguished [7].

The aim of this research is to determine the anatomical features of Carlina corymbosa L., Carthamus dentatus Vahl. and Picnomon acarna (L.) Cass., which are members of the Cardueae tribe.

\section{Material and Methods}

\subsection{Study areas and selected species}

Carlina corymbosa L., Carthamus dentatus Vahl. and Picnomon acarna (L.) Cass. were collected in August 2018 from natural environments in Milas, Muğla (Figure 1). Their collection localities were as follows: Carlina corymbosa and Picnomon acarna, N 37²1'52.503", E 2748'11.386" 62 m.; Carthamus

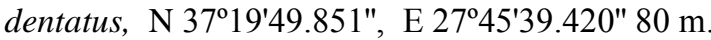

The taxonomic descriptions of all species were made according the Flora of Turkey [1]. 


\subsection{Sampling}

Root, stem and leaves of species were fixed in $70 \%$ ethanol for the anatomical studies. Cross sections were taken from each plant material by using razor blade and sections were stained with hematoxylin.
Well-stained sections were examined with BAB Image Analysing Systems Microscope (BAB-95) and photographed with BAB Microscope Camera. Anatomical structures were measured using BAB measurement program.
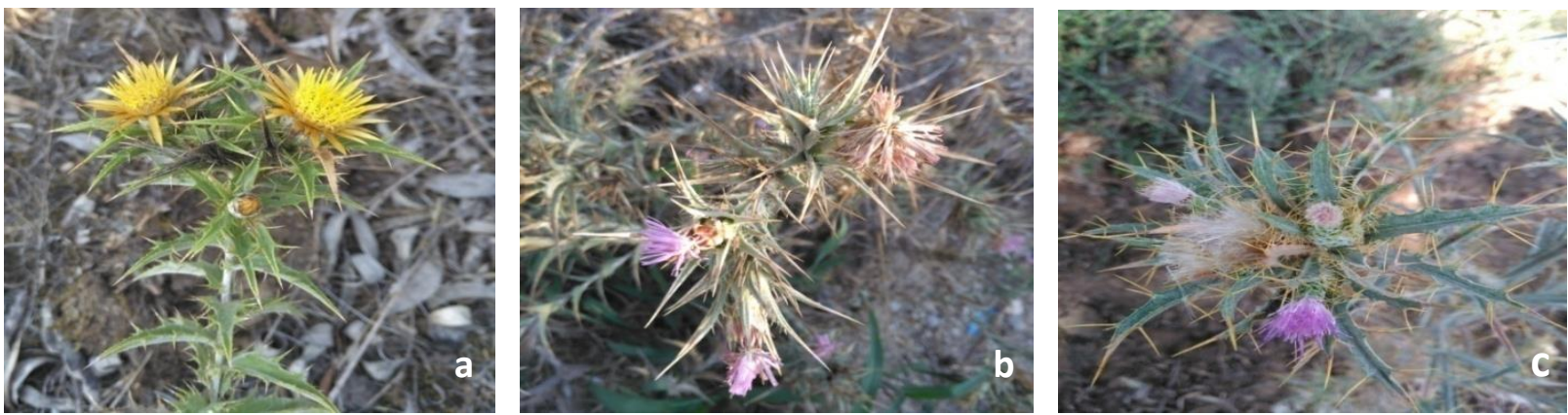

Figure 1. a) Carlina corymbosa, b) Carthamus dentatus, c) Picnomon acarna

\section{Results and Discussion 3.1 Carlina corymbosa}

In root cross section, secondary growth was observed. On the outermost, there is thick and multi-layered periderm. There are secretory ducts in the secondary cortex. The cambium cells, which between phloem and xylem, and the sclerenchyma tissues are clearly distinguished. Pith rays consist of distinct and 2-4 layered cells. Pith is filled with metaxylem (Figure 2).

The stem of $C$. corymbosa is almost circular. Uniseriate epidermis, consisting of rectangular-shaped cells surrounded by thick cuticle, is observed in cross section of the stem. The periderm layer consist of different sized and shaped cells. Endodermis and vascular bundles can be clearly distinguished. Sclerenchyma consists of 4-8 layered cells and the cambium is not very distinguishable. Phloem and xylem are well developed. The stem contains bicollateral vascular bundles. The pith is filled by oval and different sized parenchyma cells. In addition, calcium oxalate crystals are found in pith (Figure 3).

In cross section of $C$. corymbosa leaf, there is a uniseriate epidermis with thin cuticle on adaxial and abaxial surfaces. Surface of both epidermis are covered with trichomes. Glandular and non-glandular trichome types are present. Uniseriate filiform trichome with elongated apical cells and capitate stalked trichomes are observed. Another trichome (bulbiferous flagellate trichome) feature of the observed was as follows: stalk 2-celled, the lenght of the cells more than the width, second stalk cell swollen; apical cells long, flagellate. Dorsiventral mesophyll and bicollateral vascular bundles are observed in leaf. The midrib has only one vascular bundle. The adaxial parenchyma cells are 3-4 layered and abaxial parenchyma cells are 1-2 layered in midrib (Figure 4).
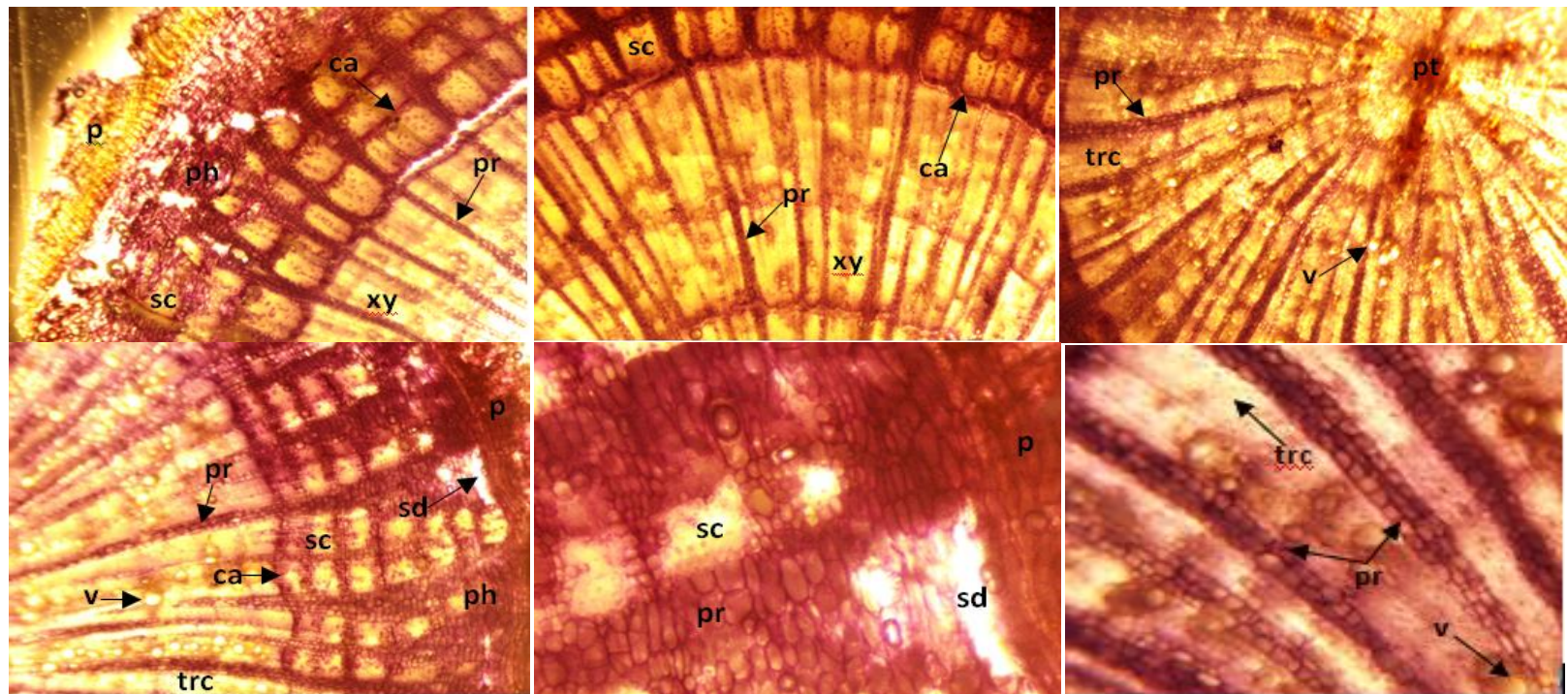

Figure 2. Root anatomy of $C$. corymbosa (ca: cambium; p: periderm; ph: phloem; pr: pith ray; pt: pith; sc: sclerenchyma; sd: secretory duct; trc: tracheid; v: vessel; xy: xylem) 


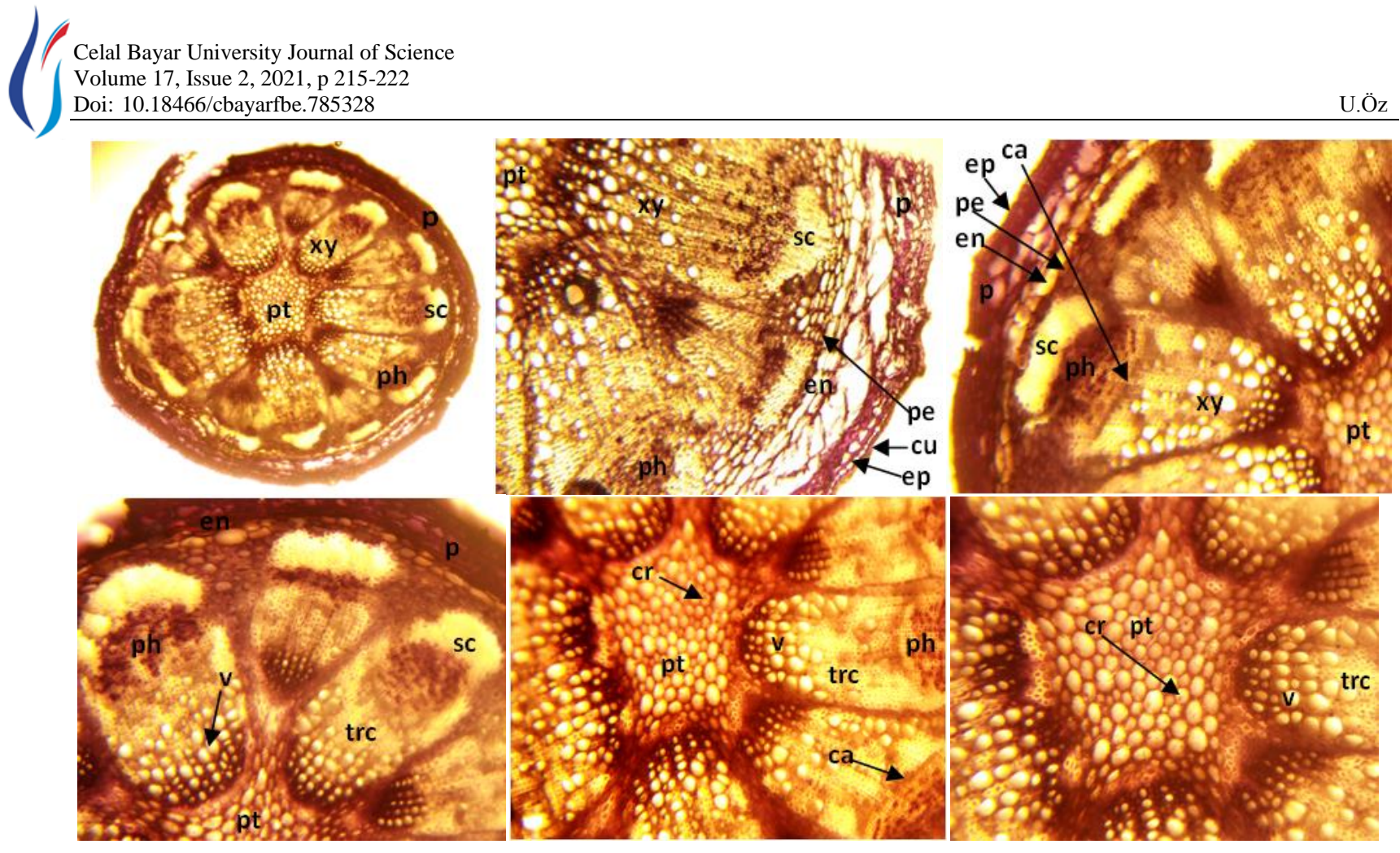

Figure 3. Stem anatomy of C. corymbosa (ca: cambium; cr: calcium oxalate crystals; cu: cuticle; ep: epidermis; en: endodermis; p: periderm; pe: pericycle; ph: phloem; pt: pith; sc: sclerenchyma; sd: secretory duct; trc: tracheid; v: vessel; xy: xylem)

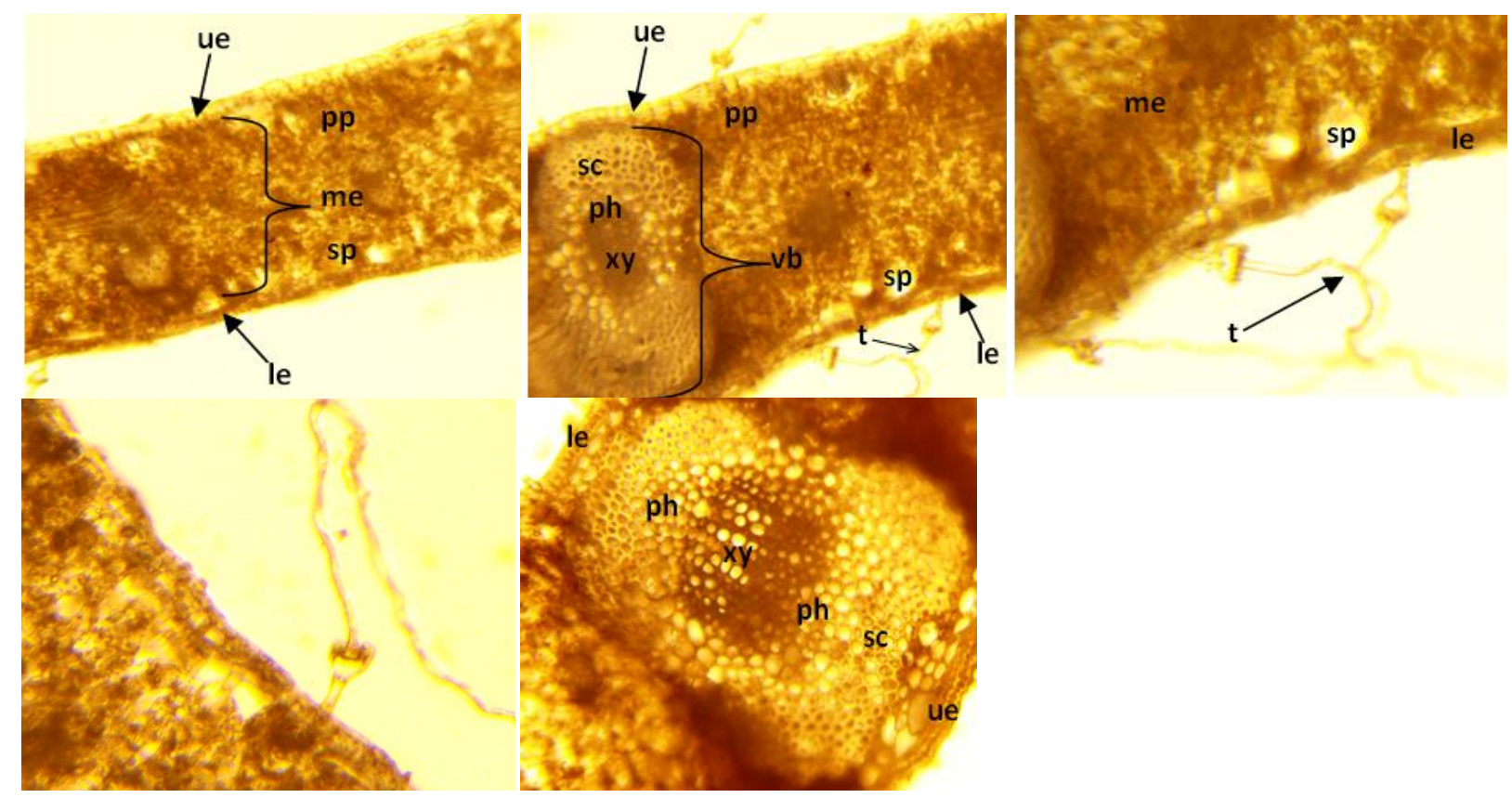

Figure 4. Leaf anatomy of $C$. corymbosa (le: lower epidermis; me: mesophyll; ph: phloem; pp: palisade parenchyma; sc: sclerenchyma; sp: spongy parenchyma; t: trichome; ue: upper epidermis; vb: vascular bundle; xy: xylem

\subsection{Carthamus dentatus}

Periderm and partially crushed epidermis are observed in the outermost part of the root cross section obtained from $C$. dentatus. There are secretory ducts in cortex and it is observed multi-layered sclerenchyma above the phloem. The cambium is clearly distinguished. Xylem is well developed and there are 2-5 layered pith rays. In addition to this, the pith is filled by xylem elements (Figure 5). 

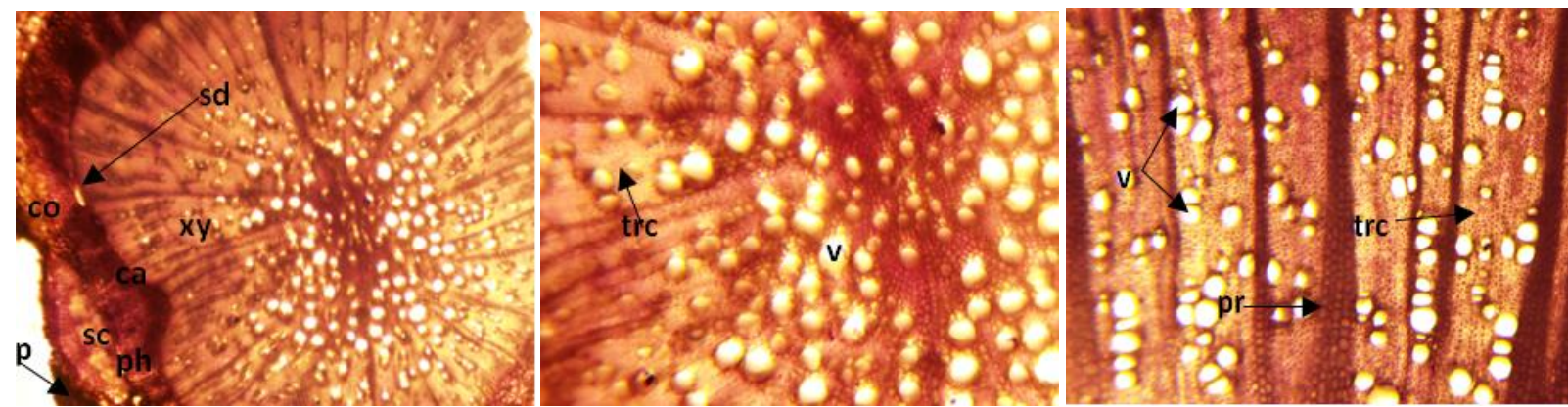

Figure 5. Root anatomy of $C$. dentatus (ca: cambium; co: cortex; p: periderm; ph: phloem; pr: pith ray; sc: sclerenchyma; trc: tracheid; v: vessel; xy: xylem)

In the stem cross section taken by $C$. dentatus, the epidermis is determined as monolayered which is composed of rectangular or oval cells. The epidermis contains multicellular non-glandular unbranched and multicellular glandular trichomes. The periderm, consisting of different sized and shaped cells, is located underneath the epidermis. The cortex cells are observed flattened in a narrow region. There are resin ducts in the cortex and also cambium is distinguishable between phloem and xylem. Sclerenchyma which between cortex and vascular bundles, consists of 4-10 layered cells. Vascular bundles are bicollateral. Pith rays consist of 12 layered oval and rectangular cells. The pith is filled with by hexagonal and oval parenchyma cells. Calcium oxalate crystals are present in pith (Figure 6).
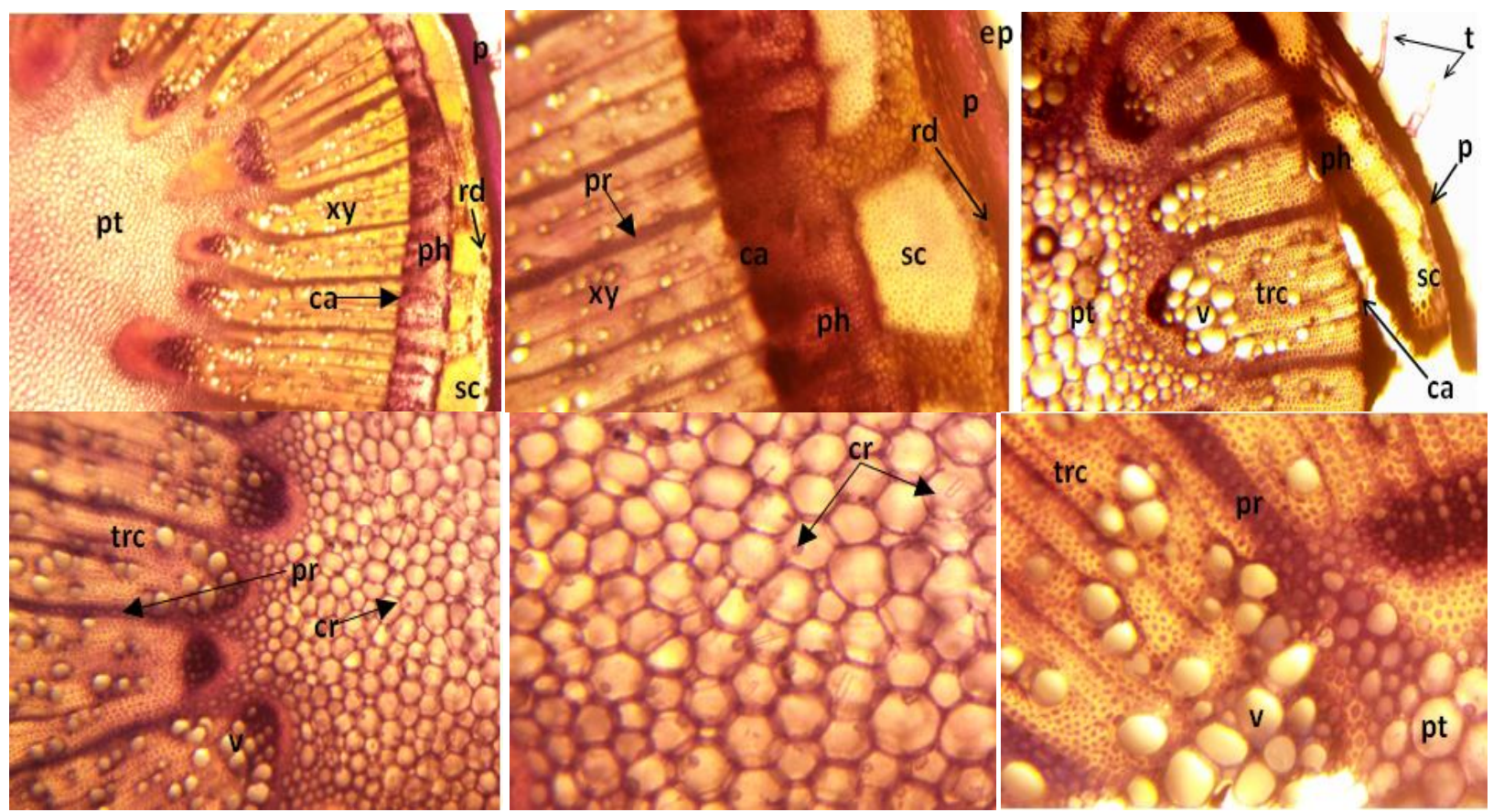

Figure 6. Stem anatomy of $C$. dentatus (ca: cambium; cr: calcium oxalate crystals; ep: epidermis; p: periderm; ph: phloem; pr: pith ray; pt: pith; rd: resin duct; sc: sclerenchyma; trc: tracheid; v: vessel; xy: xylem)

In the cross section of leaf, there is a uniseriate epidermis with thin cuticle on adaxial and abaxial surfaces. Surface of both epidermis are covered with multicellular eglandular and multicellular glandular trichomes. Many different types of trichomes were identified in the leaf cross section. The trichomes were multicellular nonglandular unbranched and multicellular glandular. Trichomes are observed as uniseriate and biseriate. The trichomes observed are as follows: long stalked capitate, one cell shriveled multicellular non glandular, conical, biseriate pedunculata glandular, biseriate vesicular glandular, short stalked capitate, sessile two-celled glandular, uniseriate multicellular non-glandular trichome. Collateral vascular bundles are observed in unifacial leaf. The midrib has only one vascular bundle and vascular bundle is surrounded by a sheath of sclerenchyma. Small collateral vascular bundles are observed in the mesophyll (Figure 7) 

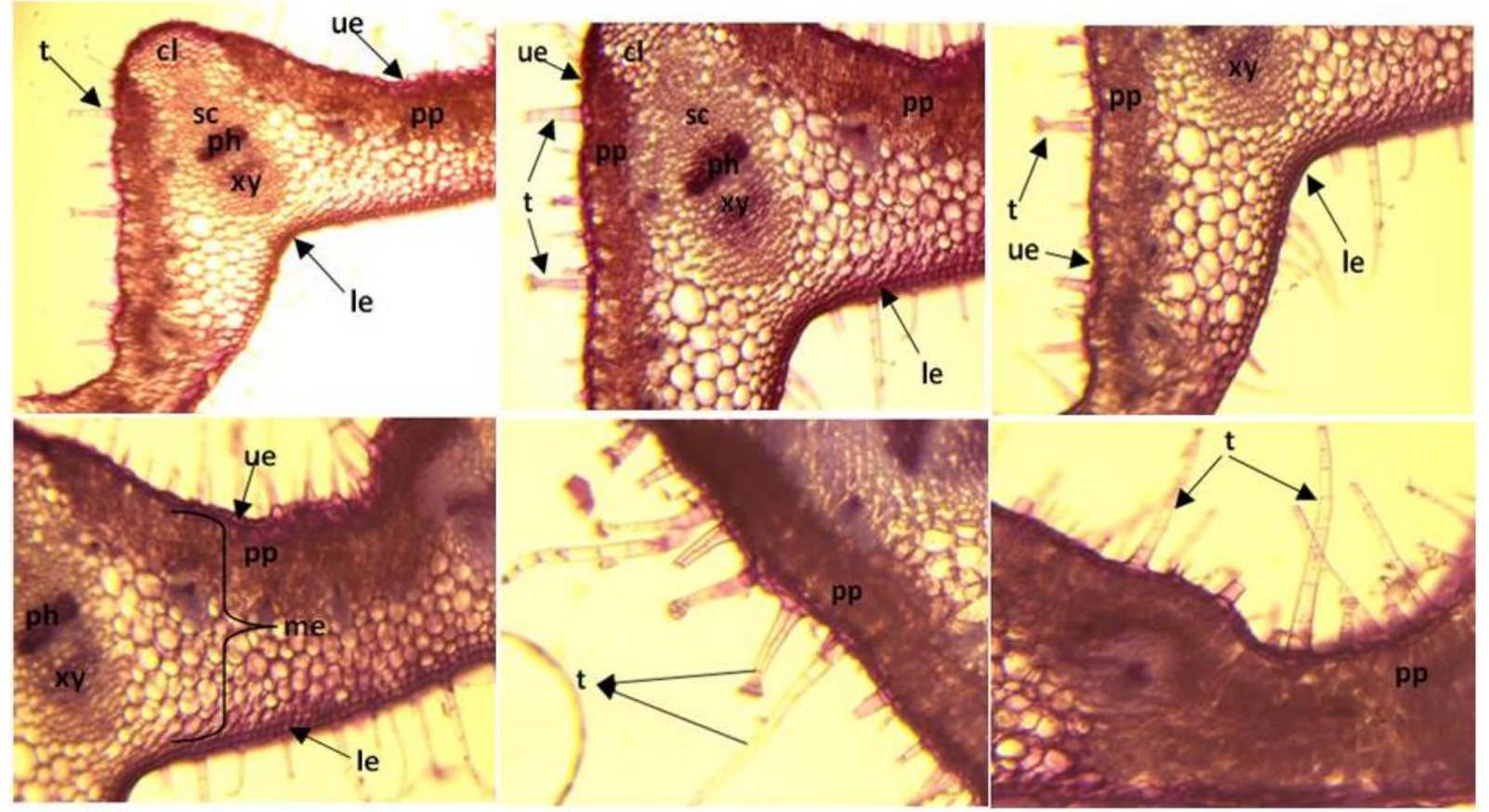

Figure 7. Leaf anatomy of $C$. dentatus (cl: collenchyma; le: lower epidermis; me: mesophyll; ph: phloem; pp: palisade parenchyma; sc: sclerenchyma; t: trichome; ue: upper epidermis; xy: xylem)

\subsection{Picnomon acarna}

In the root cross section, periderm layer consisting of multi-layered, irregularly shaped cells are observed on the outermost and the partially crushed epidermis is

The endodermis appears as a thin line and is not easily distinguishable. Cambium cells located between phloem identified. Secretory ducts are observed in the cortex. and xylem are distinct. The pith consists of differently shaped parenchyma cells (Figure

$8)$.
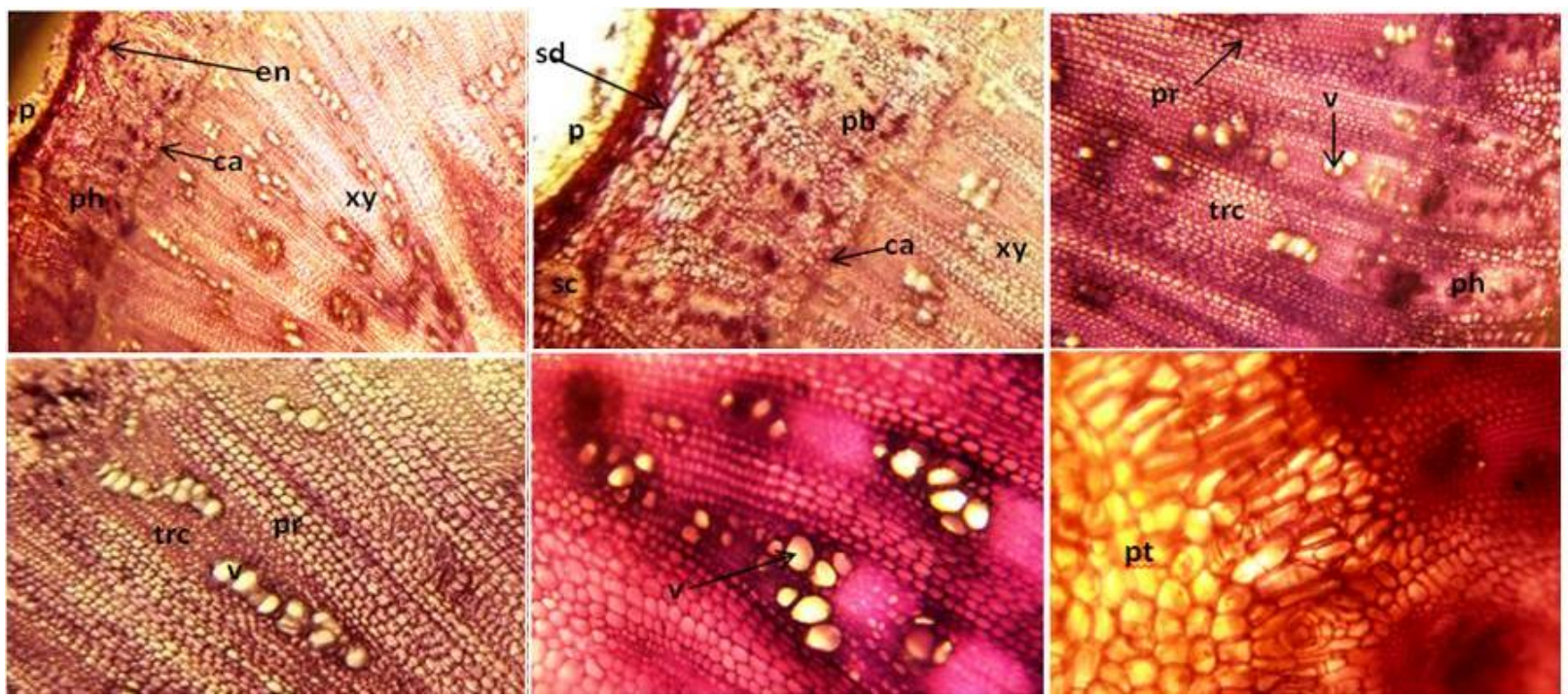

Figure 8. Root anatomy of $P$. acarna (ca: cambium; en:endodermis; p: periderm; ph: phloem; pr: pith ray;pt: pith; sc: sclerenchyma; sd: secretory duct; trc: tracheid; v: vessel; xy: xylem)

There is a thick periderm layer, consisting of different sized and shaped cells, on the outermost surface of the stem. A narrow cortex is observed in the cross section and secretory ducts in cortex are present. The central cylinder is surrounded by an endodermis and pericycle is clearly distinguishable. Multi-layered pith ray are observed between bicollateral vascular bundles. The cambium is distinguishable between phloem and xylem. Sclerenchyma consists of 3-10 layered cells. The pith contains large polygonal and hexagonal parenchymatous cells (Figure 9). 


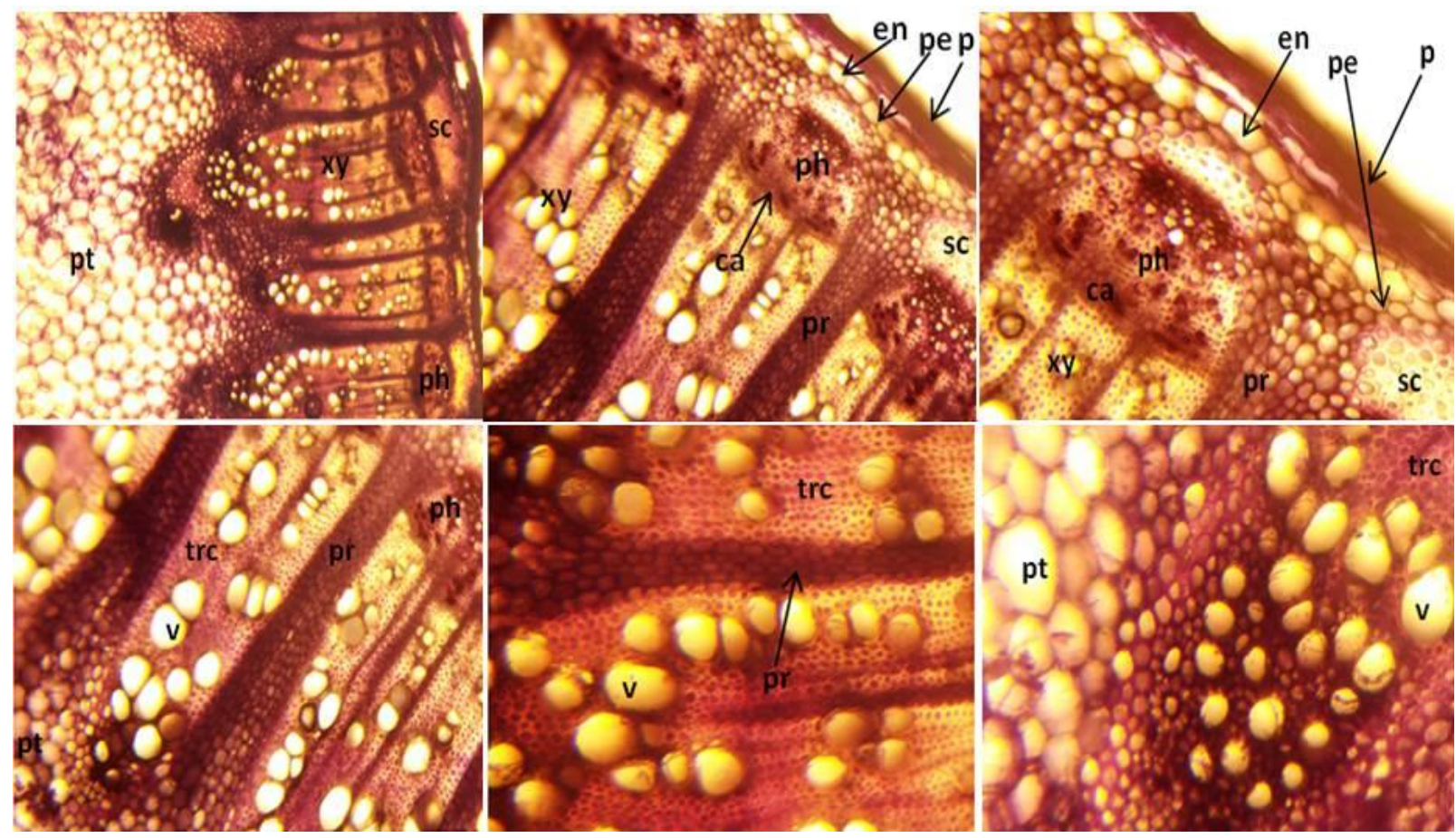

Figure 9. Stem anatomy of $P$. acarna (ca: cambium; en: endodermis; p: periderm; pe: pericycle; ph: phloem; pt: pith; pr:pith ray; sc: sclerenchyma; trc: tracheid; v: vessel; xy: xylem)

In the cross section of leaf, there is a uniseriate epidermis with thin cuticle on adaxial and abaxial surfaces. Epidermis cells are observed square or rectangular. Surface of both epidermis are covered with whip-like and flagellate-filiform trichomes. Unifacial mesophyll are observed in leaf. Vascular bundles are observed in the middle part of parenchyma tissue in the mesophyll. The midrib has three collateral vascular bundles. The upper and lower parts of the vascular bundles are surrounded by sclerenchyma (Figure 10).
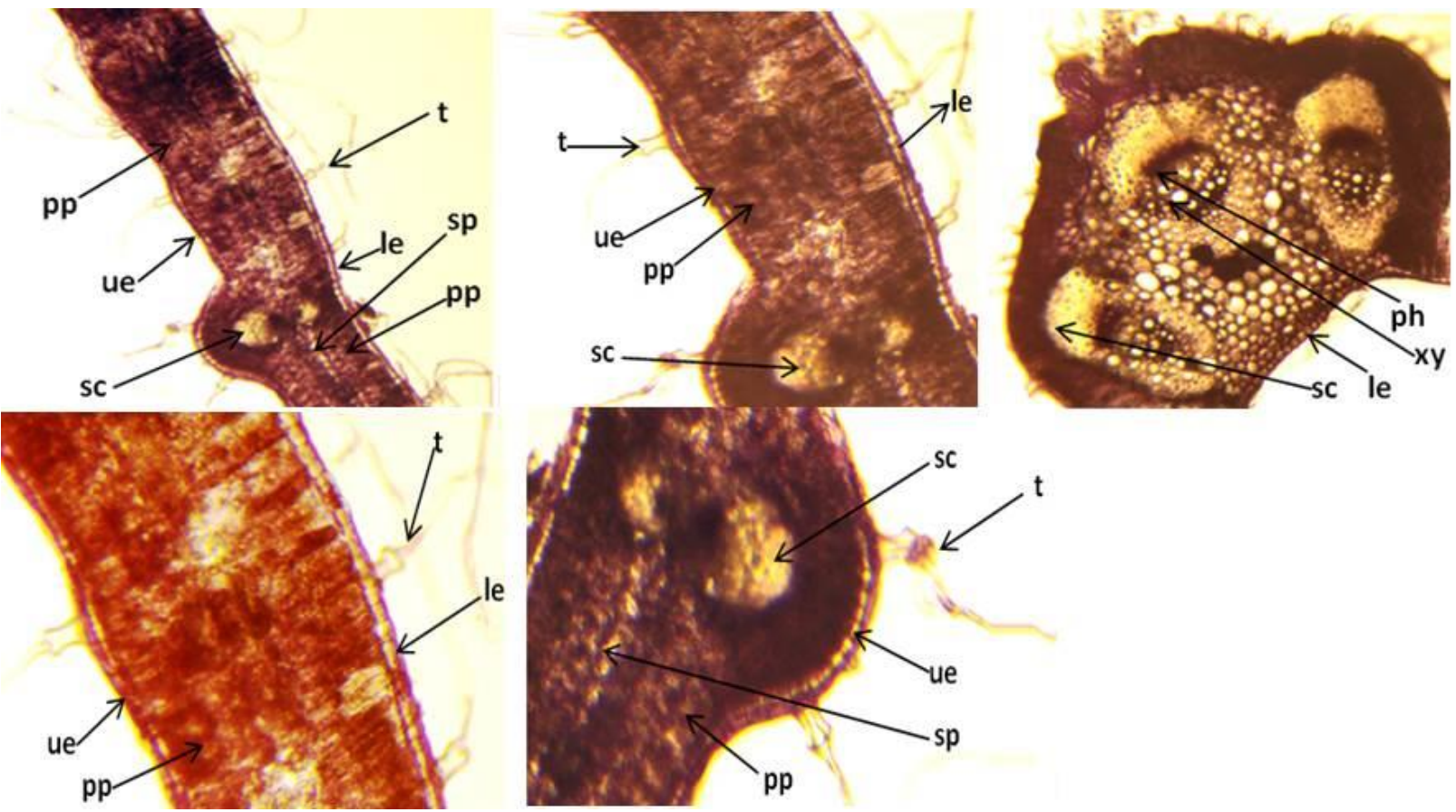

Figure 10. Leaf anatomy of P.acarna (le: lower epidermis; ph: phloem; pp: palisade parenchyma; sc: sclerenchyma; sp: spongy parenchyma; t: trichome; ue: upper epidermis; xy: xylem) 
Table 1. Measurements of anatomical structures of species

\begin{tabular}{llll}
\hline Cross section of plants & Carlina corymbosa & Carthamus dentatus & Picnomon acarna \\
\hline Root & $5753.75 \pm 400.52$ & $2880.76 \pm 327.65$ & $6919.89 \pm 1453.54$ \\
\hline Root diameter $(\mu \mathrm{m})$ & $300.06 \pm 62.41$ & $120.22 \pm 25.83$ & $230.36 \pm 71.22$ \\
\hline Periderm thickness $(\mu \mathrm{m})$ & $125.56 \pm 23.57$ & $162.61 \pm 10.50$ & $373.10 \pm 45.99$ \\
\hline Phloem thickness $(\mu \mathrm{m})$ & $1847.16 \pm 157.75$ & $832.06 \pm 99.93$ & $1561.37 \pm 186.44$ \\
\hline Xylem thickness $(\mu \mathrm{m})$ & $39.38 \pm 13.81$ & $42.83 \pm 12.48$ & $38.30 \pm 8.91$ \\
\hline Vessel diameter $(\mu \mathrm{m})$ & & & \\
\hline Stem & 12 & $23-24$ & $26-27$ \\
\hline Vascular bundles number & $106.14 \pm 21.75$ & $70.16 \pm 22.72$ & $69.72 \pm 14.00$ \\
\hline Periderm thickness $(\mu \mathrm{m})$ & $95.56 \pm 15.63$ & $72.51 \pm 12.17$ & $147.63 \pm 38.99$ \\
\hline Thickness of sclerenchyma $(\mu \mathrm{m})$ & $163.81 \pm 18.58$ & $200.85 \pm 36.84$ & $198.64 \pm 42.36$ \\
\hline Phloem thickness $(\mu \mathrm{m})$ & $471.77 \pm 52.14$ & $963.90 \pm 204.43$ & $909.24 \pm 145.92$ \\
\hline Xylem thickness $(\mu \mathrm{m})$ & $29.58 \pm 6.75$ & $35.94 \pm 10.42$ & $51.61 \pm 14.65$ \\
\hline Vessel diameter $(\mu \mathrm{m})$ & $429.20 \pm 52.86$ & $1145.85 \pm 88.75$ & $1727.55 \pm 277.26$ \\
\hline Pith diameter $(\mu \mathrm{m})$ & & & \\
\hline Leaf & $18.75 \pm 2.61$ & $16.92 \pm 2.45$ & $13.94 \pm 1.80$ \\
\hline Adaxial epidermis thickness $(\mu \mathrm{m})$ & $21.08 \pm 2.54$ & $16.39 \pm 3.20$ & $12.15 \pm 2.02$ \\
\hline Abaxial epidermis thickness $(\mu \mathrm{m})$ & $412.19 \pm 34.99$ & $311.73 \pm 61.67$ & $188.69 \pm 19.55$ \\
\hline Mesophyll thickness $(\mu \mathrm{m})$ & $668.65 \pm 14.91$ & $757.07 \pm 115.87$ & $652.31 \pm 32.99$ \\
\hline Midrib thickness $(\mu \mathrm{m})$ & 1 & 1 & 3 \\
\hline Number of vascular bundles in midrib & & & \\
\hline
\end{tabular}

$\mu \mathrm{m}$ : micrometer

The root, stem and leaf anatomical features of all species are given as above. In addition, some anatomical characters of these species were measured and indicated Table 1.

The species belonging to the Asteraceae family have different anatomical structures [8].Trichomes are important characteristic in phylogenetic studies related to the Asteraceae family [9-11]. In a study investigating the anatomy of the $C$. dentatus [12], it was stated that this species has glandular and non-glandular trichome, but the trichome types are not mentioned in detail. Long stalked capitate, one cell shriveled multicellular non glandular, conical, biseriate pedunculata glandular, biseriate vesicular glandular, short stalked capitate, sessile two-celled glandular, uniseriate multicellular non-glandular trichomes has been identified in this research. C. corymbosa contains uniseriate filiform, capitate stalked and bulbiferous flagellate trichomes whereas $P$. acarna has whip-like and flagellate-filiform trichomes. One of the distinguishing features of Asteraceae is the presence of secretory ducts [1314].The secretory ducts are observed in all species used in the research.

Similar results were obtained when these species belonging to the same tribus were examined. In the root cross sections, the best secondary growth was observed in the $C$. corymbosa and periderm was thicker than others. However, in the root section of P. acarna, the pith was filled with parenchyma cells as different from the others and root diameter is highest in the this species. In the Asteraceae family, the vascular bundles and leaf midrib differences are also valuable anatomical features [15-19].The maximum number of vascular bundle in the stem was determined in P. acarna. Bicollateral vascular bundle was observed in the stem of all species used in the study. While collateral vascular bundle was determined in the leaf cross sections of $C$. dentatus and P..acarna, bicollateral vascular bundle was detected in the $C$. corymbosa. Also, $C$. corymbosa and $C$. dentatus have only one vascular bundle in the midrib but $P$. acarna has three vascular bundles.

There are calcium oxalate crystals in the tribe Cardueae. In a study of Cardueae [20], it was stated that $C$. dentatus contains prismatic and styloid crystals. Likewise, calcium oxalate crystals were observed in the pith of stem in all species in this study.

\section{Conclusion}

This study gives information about the anatomical features of the root, stem and leaf sections of Carlina corymbosa, Carthamus dentatus and Picnomon acarna. In the study, it was determined trichomes with different characteristics and this trichome diversity will contribute to the trichome micromorphology of Asteraceae. In addition, the results obtained from the study will constitute resource for the another research related to the anatomy of the Cardueae.

\section{Author's Contributions}

Ummahan Öz: Responsible of all processes; planning the research, obtaining and analyzing data, drafting and writing the article. 


\section{Ethics}

There is no ethical issues after the publication of this article.

\section{References}

1. Davis, P. Flora of Turkey and the East Aegean Islands, Vol.5; Edinburgh University Press: Edinburgh, 1975.

2. El-Gazzar ,A, El-Husseini, N, Khafagi ,A, Mostafa, N. 2019 Computer-generated Keys to the Egypt.9.The Spiny Taxa of Asteraceae. Egyptian Journal of Botany; 59 (1): 107-138.

3. Seçmen, Ö, Gemici, Y, Görk, G, Bekat, L, Leblebici, E. Tohumlu Bitkiler Sistematiği; Ege Üniversitesi Yayınları, Fen Fakültesi Kitapları Serisi No: 116, İzmir, Turkey, 2011.

4. Kurt, A, Ozcan , M, Colak, N, Ozogul, Y, Glew, R, Ozogul, F Ayaz, FA. 2019. Fatty Acids of Oil and Antioxidant Capacity of Phenolics from Fruits of 11 Cardueae (Carduoideae, Asteraceae) Taxa From Northeast Anatolia (Turkey). Botanica Serbica; 43(1): $31-45$.

5. Ozcan, M, Akinci, N.2019. Micromorpho-anatomical Fruit Characteristics and Pappus Features of Representative Cardueae(Asteraceae) Taxa: Their Systematic Significance. Flora: 256: 16-35.

6. Dere, S, Aktas Akcin, T. 2017. Anatomical and Micromorphological Properties of Some Tanacetum L. (Asteraceae) Taxa from Turkey and their Systematic İmplications. Acta Botanica Croatica; 76(2): 138-145.

7. Haratym, W, Weryszko-Chmielewska, E, Konarska, A. 2020. Microstructual and Histochemical Analysis of Aboveground Organs of Centaurea cyanus Used in Herbal Medicine. Protoplasma; 257: 285-298.

8. Karahan, F. 2020. Morphology, Anatomy, Palynology and Achene Micromorphology of Bellis L. (Asteraceae) Species from Turkey. Acta Botanica Croatica; 79(1): 59-67.

9. Makbul, S, Coskuncelebi, K, Beyazoğlu, O. 2011. Notes on the Stem Anatomy of Scorzonera (Asteraceae) Taxa from Northeast Turkey. Phytologia Balcanica; 17(1): 113-121.

10. Muravnik, L, Kostina, O, Shavarda, Alexey. 2016. Glandular trichomes of Tussilago farfara (Senecioneae, Asteraceae). Planta; 244: 737-752.
11. Muravnik, L, Kostina, O, Mosina, A. 2019. Glandular trichomes of the leaves in three Doronicum species (Senecioneae, Asteraceae): morphology, histochemistry and ultrastructure. Protoplasma; 256: 789-803.

12. Yağci Tuzun, C, Tarikahya, Hacioglu, B, Bulbul, AS, Arslan, Y, Subasi, I. 2019. Comparative Anatomical Studies on Some Species of Carthamus L. in Turkey. Fresenius Environmental Bulletin; 28(5): 4072-4079

13. Zuccolotto, T, Bressan, J, Lourenço, A, Bruginski, E, Veiga, A, Marinho, J, Raeski, P, Heiden, G, Salvador, M, Murakami, F, Budel, J, Campos, F. 2019. Chemical, Antioxidant, and Antimicrobial Evalutaion of Essential oils and an Anatomical Study of the Aerial Parts from Baccharis Species (Asteraceae). Chemistry \& Biodiversity; 16(4).

14. Gavrilovic, Milan, Rancic, D, Garcia-Jacas, N, Susanna, A, DajicStevanovic, Z, Marin, P, Javackovic, P. 2020. Anatomy of Balkan Amphoricarpos Vis. (Cardueae, Asteraceae) taxa. Biologia; 75: 209-222.

15. Inceer, $H$, Ozcan, $M$. 2011. Leaf anatomy as an additional taxonomy tool for 18 taxa of Matricaria L. and Tripleurospermum Sch. Bip. (Anthemideae- Asteraceae) in Turkey. Plant Systematics and Evolution; 296:205-215.

16. Aydin, Ö, Coşkunçelebi, K, Güzel, ME. 2013. A contribution to taxonomy of Centaurea including Psephellus (Asteraceae) based on anatomical and molecular data. Turkish Journal of Botany. 37: 419-427.

17. Ozcan, M, Unver, M, Eminagaoglu, O. 2014. Comparative anatomical and ecological investigations on some Centaurea (Asteraceae) taxa from Turkey and their taxanomic significance. Pakistan Journal of Botany. 46(6): 1287-1301.

18.Ekeke ,C, Mensah, SI. 2015. Comparative Anatomy of Midrib and İts Significance in the Taxanomy of the Family Asteraceae from Nigeria. Journal of Plant Sciences; 10(5): 200-205.

19.Ozcan, M, Demiralay, M, Kahriman, A. 2015. Leaf anatomical notes on Cirsium Miller (Asteraceae, Carduoideae) from Turkey. Plant Systematics and Evolution; 301: 1995-2012.

20. Kartal, C. 2016. Calcium Oxalate Crystals in Some Species of the Tribe Cardueae (Asteraceae). Botanical Sciences; 94(1): 107119. 